\title{
Monitoring for Photovoltaic in Outer Island
}

\author{
W Sunanda ${ }^{*}$, E A Pratama ${ }^{2}$, H Subastiyan $^{3}$, Y Tiandho ${ }^{4}$, D Novitasari $^{5}$ \\ ${ }^{1}$ Department of Electrical Engineering, Universitas Bangka Belitung, Bangka, Indonesia \\ ${ }^{2}$ Bangka Techno Hub, Bangka, Indonesia \\ ${ }^{3}$ Bangka Techno Hub, Bangka, Indonesia \\ ${ }^{4}$ Department of Physics, Universitas Bangka Belitung, Bangka, Indonesia \\ ${ }^{4}$ Centre for Energy Studies, Universitas Gadjah Mada, Indonesia \\ *Email: wahrisunanda@gmail.com
}

\section{Article Information}

Received:

16 October 2020

Received in revised form:

5 November 2020

Accepted:

5 December 2020

Volume 2, Issue 2, December 2020

pp. $68-73$

(C) Universitas Lampung

\begin{abstract}
Photovoltaic is a renewable energy source that can optimally be used on outer islands and areas that are difficult to reach by the main electrical system network. With good solar energy intensity on a daily, it adds to the advantages of using photovoltaics. In this regard, it is necessary to make a prototype for monitoring the photovoltaic output parameters to measure photovoltaic performance. The parameters that will be monitored on $50 \mathrm{Wp}$ photovoltaic used in this research are voltage using a voltage sensor, current using an ACS712 sensor, and the real power generated. The monitoring results are stored in a database and monitored in realtime based on the website's setting. So that this prototype can be used in several outer islands in Bangka Belitung, which is geographically an archipelago.
\end{abstract}

.Keywords: photovoltaic, voltage, current, real power, outer island.

\section{INTRODUCTION}

$\mathrm{O}$ ne of the provinces consisting of various small slands in Indonesia is the Bangka Belitung Islands Province. Bangka Belitung Islands has an ocean area of $65.301 \mathrm{~km}^{2}$ and a land area of $16.242 \mathrm{~km}^{2}$ [1], and it is composed of two main islands, namely Bangka and Belitung Islands, as shown in Figure 1.

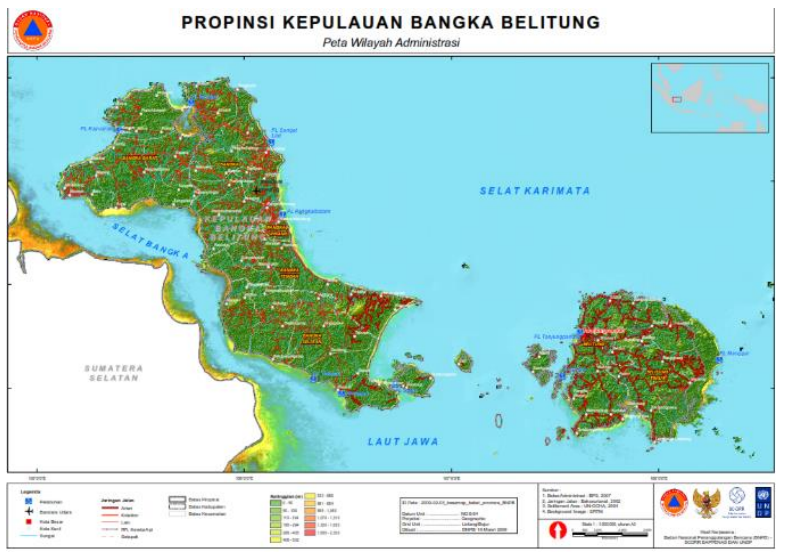

Figure 1. Map of Bangka Belitung Island Province [2]

Based on geography, Bangka Island is surrounded by Nangka, Penyu, Burung, Lepar, Pongok, Gelasa, Panjang, and Tujuh islands [1]. Also, Belitung is surrounding by Lima, Lengkuas, Selindung, Pelanduk, Seliu, Nadu, Mendanau, Batu Dinding, Sumedang, and other small islands [1].

The existence of outer islands whose position is far from the main island requires a supply of electrical energy to improve peoples' quality of life on the local island. With the intensity of sun's intensity up to 4.95 $\mathrm{kWh} / \mathrm{m} 2$ day [3], the outer islands in the Bangka Belitung Province can utilize the energy's potential to be converted to electrical energy through the use of photovoltaics. This also certainly supports by diversifying the source of electrical energy for the Bangka Belitung Province, which currently has a population of $1,459,873$ people and 449,450 customers [1] dominated by diesel and steam power plants also in a small amount from bioenergy. Dependence on fossil energy sources with the availability of infrastructure and limited access, as well as high prices make the use of renewable energy, including those from solar energy sources a necessity and choice in meeting the electrical energy needs of residents on small and outer islands [4][7].

One of the main problems in utilizing photovoltaics on the outer islands is difficult to monitor in realtime. Most citizens of the outer island do not understand 
photovoltaic technology well. On the other hand, photovoltaic systems need to be monitored regularly to prevent serious problems that may arise.

Several studies related to monitoring photovoltaic performance [8]-[12] include monitoring using a smartphone [13], monitoring Grid Connected UtilityScale for PV Power Plant [14], based on the website [15]-[16] and internet-based of things [17]-[20]. Therefore, a prototype test will be carried out using one unit of $50 \mathrm{Wp}$ photovoltaic equipped with ACS712 current sensor, voltage sensor, and ESP8266 module to monitor voltage, current, and real power stored a database, it can be displayed on a website in realtime.

\section{Materials ANd MethodS}

This study's monitoring system measures the output voltage and current from the solar panel and solar charger controller. In this research, we are using $50 \mathrm{Wp}$ solar panels with polycrystalline silicon type, and the solar panels are placed in an open place and get direct sunlight. Block diagram of system in Figure 1.

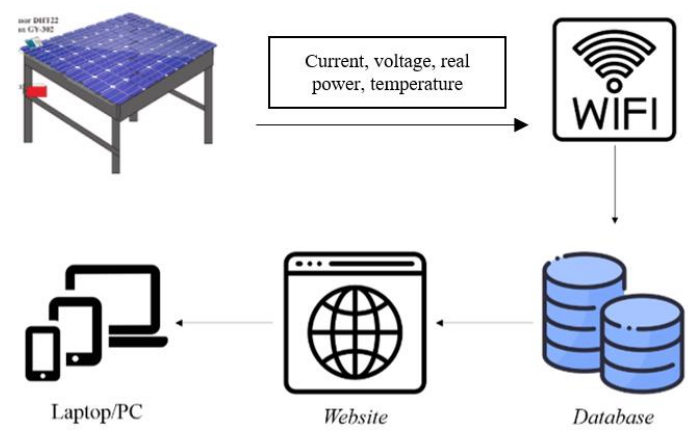

Figure 1. Block diagram

Voltage sensor and current sensor ACS712 are using to measure voltage and current. Both sensors are connected to Arduino. The voltage sensor test is done by connecting pin $\mathrm{S}$ on the sensor with pin $\mathrm{A} 0$ on Arduino and pin - on the sensor with the GND pin on the Arduino. Current sensor testing is done by connecting the OUT pin on the sensor with pin A0 on Arduino, GND pin on the sensor with GND pin on Arduino, and the VCC sensor pin with pin 5V Arduino. After the sensor reads the voltage and current, the ESP8266 module connects wifi with Arduino. If Arduino is connecting to wifi, Arduino will send voltage and current data to the database. After the data is sent, it will display the data on the website that has been built. In this research, the website created consists of realtime pages, data table pages, and graph pages.. Schematically, the circuit diagram of this study is shown in Figure 2.

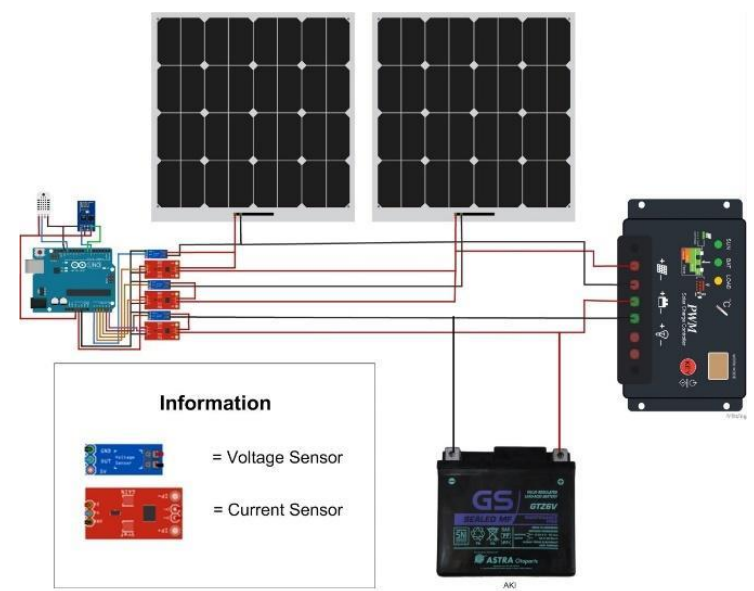

Figure 2. Circuit diagram

It made a comparison between systems and multimeters to validate the performance of the monitoring system. The accuracy level of system has expressed the difference between the measurement results and the results measured on a multimeter:

$$
\% \text { Error }=\left|\frac{M S-M M}{M M}\right| \times 100 \%
$$

Where $M S$ is a measurement by a sensor and $M M$ is a measurement by the multimeter.

\section{RESULTS AND DISCUSSIONS}

Table 1 presents the voltage sensor validation data for voltage sources ranging from 1 to $25 \mathrm{~V}$. Based on this data, and it appears that the error from the comparison between the voltage sensor with a multimeter is between $0-4.76 \%$. The highest error occurs at $1 \mathrm{~V}$. However, when the source voltage increases, the error decreases. According to these results, it can be stated that the voltage sensor system used has good accuracy to measure the voltage. Moreover, the output of the solar panels used is more than $1 \mathrm{~V}$.

Table 1. Validation for voltage sensor

\begin{tabular}{cccc}
\hline $\begin{array}{c}\mathrm{V}_{\text {source }} \\
(\mathrm{V})\end{array}$ & $\begin{array}{c}\text { Voltage sensor } \\
(\mathrm{V})\end{array}$ & $\begin{array}{c}\text { Multimeter } \\
(\mathrm{V})\end{array}$ & $\begin{array}{c}\text { Error } \\
(\%)\end{array}$ \\
\hline 1 & 1.1 & 1.05 & 4.76 \\
2 & 2.06 & 2.04 & 0.98 \\
3 & 3.14 & 3.11 & 0.96 \\
4 & 4.07 & 4.06 & 0.25 \\
5 & 5.15 & 5.12 & 0.59 \\
6 & 6.12 & 6.10 & 0.32 \\
7 & 7.09 & 7.08 & 0.13 \\
8 & 8.08 & 8.07 & 0.12 \\
9 & 9.05 & 9.04 & 0.01 \\
10 & 9.99 & 10.05 & 0.60 \\
11 & 10.95 & 11.04 & 0.60 \\
12 & 11.96 & 12.04 & 0.66
\end{tabular}




\begin{tabular}{lccc}
13 & 13.06 & 13.1 & 0.31 \\
14 & 13.97 & 14.04 & 0.50 \\
15 & 15.01 & 15.11 & 0.66 \\
16 & 15.95 & 16.05 & 0.62 \\
17 & 16.98 & 17.12 & 0.82 \\
18 & 17.92 & 18.09 & 0.94 \\
19 & 18.86 & 19.06 & 1.05 \\
20 & 19.8 & 20.05 & 1.25 \\
21 & 20.84 & 21.06 & 1.04 \\
22 & 21.84 & 22.13 & 1.31 \\
23 & 22.88 & 23.07 & 0.82 \\
24 & 23.89 & 24.1 & 0.87 \\
25 & 25 & 25.06 & 0.24 \\
\hline
\end{tabular}

Table 2 presents the current sensor validation. This validation uses a constant voltage of 12 volts with variations in load from 1.2 to 6 Watt. The validation results show that the highest error percentage value is $25 \%$, and it occurs when the load is $1.2 \mathrm{~W}$. Ammeters measure currents of $0.12 \mathrm{~A}$. While the current sensor measures currents of $0.15 \mathrm{~A}$. The minimum error percentage value is $2 \%$ when the source voltage is given a load of $6 \mathrm{~W}$. Thus, and it appears that the greater the measured power, the accuracy of the current sensor will increase.

Table 2. Validation for a current sensor

\begin{tabular}{ccccc}
\hline $\begin{array}{c}\text { Source } \\
(\mathrm{V})\end{array}$ & $\begin{array}{c}\text { Load } \\
\text { (watt) }\end{array}$ & $\begin{array}{c}\text { Current } \\
\text { sensor (A) }\end{array}$ & $\begin{array}{c}\text { Amperemeter } \\
(\mathrm{A})\end{array}$ & Error(\%) \\
\hline 12 & 1.2 & 0.15 & 0.12 & 25 \\
12 & 2.4 & 0.22 & 0.21 & 5 \\
12 & 3.6 & 0.3 & 0.32 & 6 \\
12 & 4.8 & 0.44 & 0.42 & 5 \\
12 & 6 & 0.52 & 0.51 & 2 \\
\hline
\end{tabular}

Figure 3 shows the website display containing a database that is stored every 5 minutes. The picture also shows the sensor's measured voltage, the measured current from the sensor, and the real power generated.

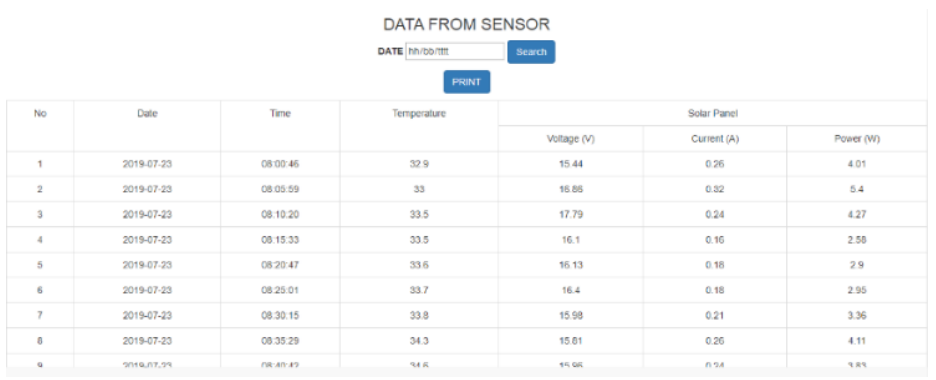

Figure 3. Database from Photovoltaic Monitoring

Whereas in figure 4 shows the website graphic display on a database. The graph displays the real voltage, current, and power at the vertical axis, while on the horizontal axis, the data is taken when the current data, voltage, and real power

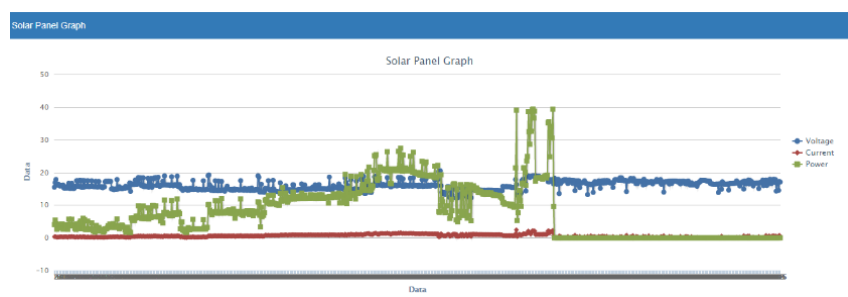

Figure 4. Result of Photovoltaic Monitoring

Figure 5 is the result of measurements on July 23, 2019 for the photovoltaic temperature and voltage. Measurements were made from 08.00 A.M. to 04.00 P.M. By taking data from the measurements, it was carried out every 5 minutes. At 08.00 A.M. with a temperature of $32.9^{\circ} \mathrm{C}$, the measured voltage from the sensor is 15.44 V. At 10.50 A.M., an increase in temperature becomes $33.3^{\circ} \mathrm{C}$ with a measured voltage from the sensor $15.08 \mathrm{~V}$. At 04.00 P.M. at a temperature of $30.8^{\circ} \mathrm{C}$, the measured voltage from the sensor 14.17 V.

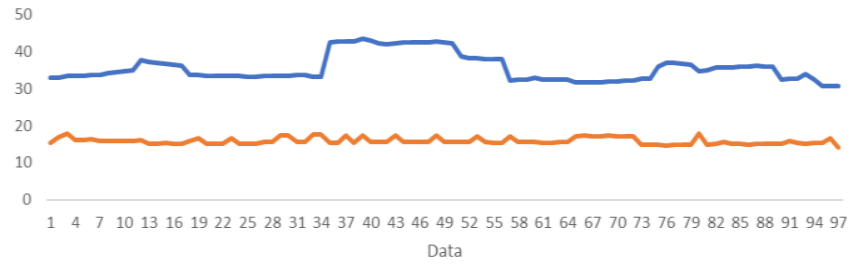
-Temperature (C) —Voltage (V)

Figure 5. Voltage and Temperature from photovoltaic on July 23

Figure 6 shows the measurements on 23 of 2019 for the measurement results of the current sensor. Data is collected every 5 minutes from measurements made from 08.00 A.M. to 04.00 P.M . At 08.00 A.M., the output current is $0.26 \mathrm{~A}$, and at $09.30 \mathrm{~A} . \mathrm{M}$., the output current is 0.34 A. While at 04.00 P.M., the output current from photovoltaic is $0.11 \mathrm{~A}$. 


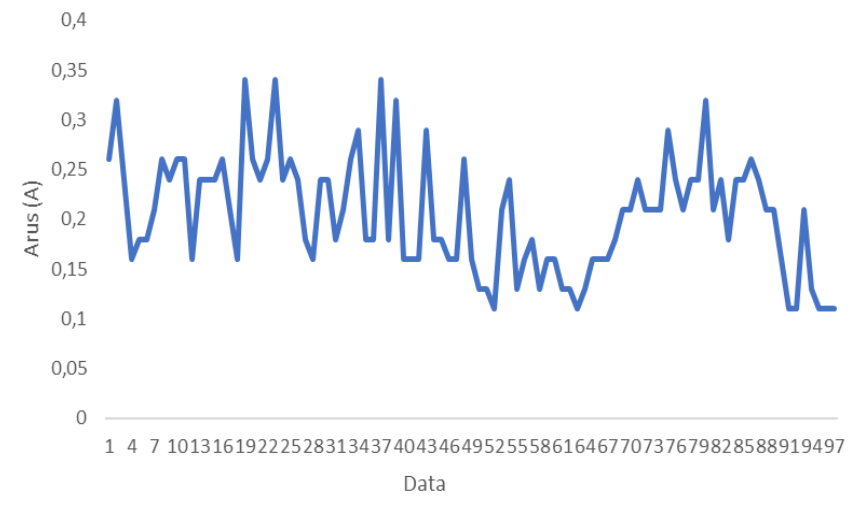

Figure 6. Current from photovoltaic on July 23

In Figure 7 is a measurement of temperature and voltage carried out on July 24, 2019. Data collection is carried out every 5 minutes which measurements are taken at 08.00 A.M. to 04.00 P.M. At 08.00 A.M. with a temperature of $35.7^{\circ} \mathrm{C}$, the measured voltage of the solar panel is $16.3 \mathrm{~V}$. Temperature at 11.05 A.M. is measured $40.5^{\circ} \mathrm{C}$ with the voltage of the solar panel $15.86 \mathrm{~V}$. Then at 04.00 P.M. with a temperature of 36 $.8^{\circ} \mathrm{C}$ measured solar panel voltage $14.76 \mathrm{~V}$.

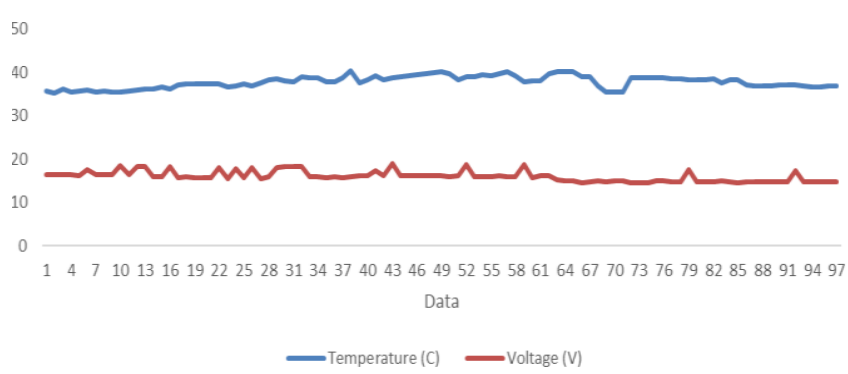

Figure 7. Voltage and Temperature from photovoltaic on July 24

Figure 8 shows the measurements on July 242019 for the measurement results of the current sensor. Data is collected every 5 minutes from measurements made from 08.00 A.M. to 04.00 P.M.. At 08.00 A.M. the photovoltaic current was $0.37 \mathrm{~A}$, while at $11.30 \mathrm{~A} . \mathrm{M}$. the measured 0.61 A. At 01.50 P.M. the measured current value was $0.11 \mathrm{~A}$.

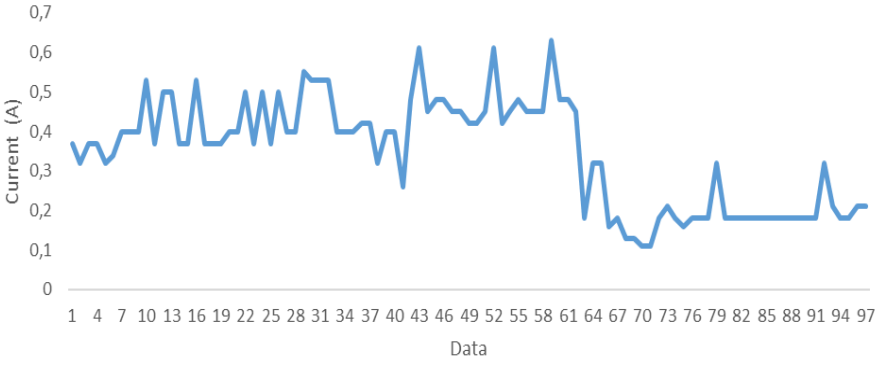

Figure 8. Current from photovoltaic on July 24

The results of voltage and temperature measurements in Figure 9 are the results of measurements on July 25 at 08.00 A.M. to 04.00 P.M. every 5 minutes. At 08.05 A.M. with a measured temperature of $34.9^{\circ} \mathrm{C}$, the photovoltaic voltage is $19.19 \mathrm{~V}$. Then at 11.05 A.M. the measured temperature is $35.5^{\circ} \mathrm{C}$ with a measured voltage of photovoltaic $14.74 \mathrm{~V}$. At 04.00 P.M., the measured temperature is $35.8^{\circ} \mathrm{C}$ with a photovoltaic voltage of $14.54 \mathrm{~V}$.

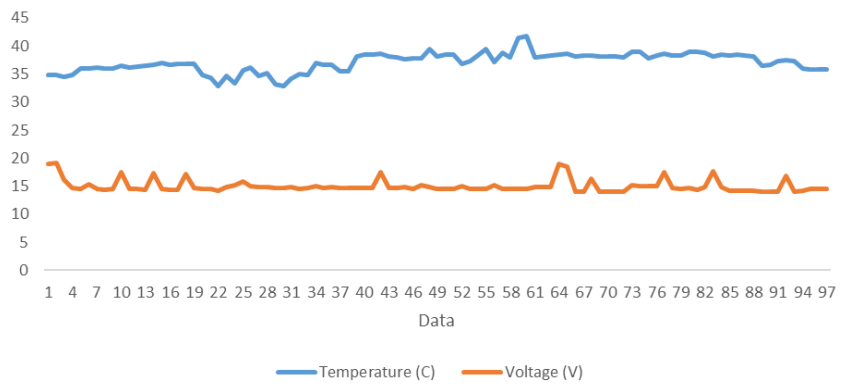

Figure 9. Voltage and Temperature from photovoltaic on July 25

Figure 10 Results from the photovoltaic currents' measurement on July 25 from 08.00 to 04.00 every 5 minutes. At 08.00 A.M. the current measured from photovoltaic $0.53 \mathrm{~A}$, while at 02.05 noon, the current measured from photovoltaic $0.78 \mathrm{~A}$.

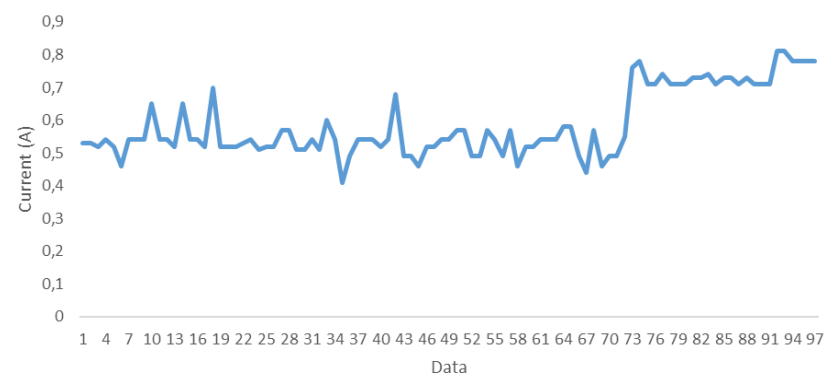

Figure 10. Current from photovoltaic on July 25

The photovoltaic efficiency in Figure 11 is the ratio between the measured real power to the potential real power generated with a maximum value of $36 \%$, a minimum value of $4 \%$, and an average of $11 \%$. 


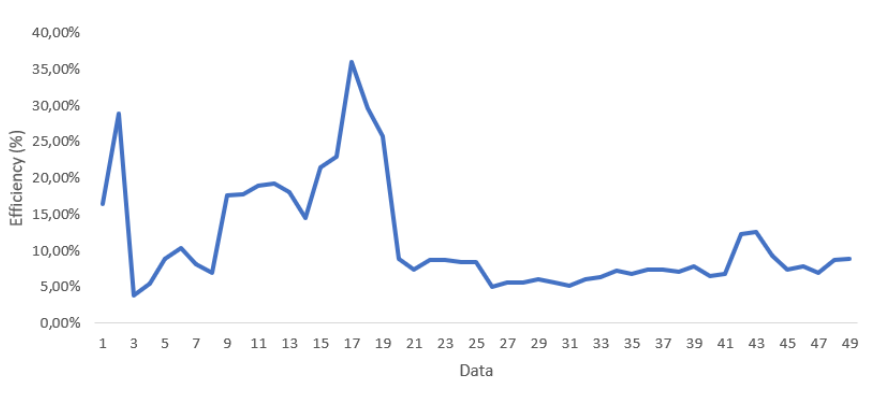

Figure 11. Efficiency of photovoltaic

\section{CONCLUSIONS}

This research built realtime photovoltaic monitoring through the website for the outer islands in Bangka Belitung islands to display the results of monitoring currents, voltages, real power, and can also measure photovoltaic's efficiency by comparing the measured real power with the potential real power that can be generated

\section{ACKNOWLEDGMENT}

We gratefully acknowledge the funding from USAID through the SHERA program - Centre for Development of Sustainable Region (CDSR). In the year 2017-2021, CDSR is led by Centre for Energy Studies - UGM.

\section{REFERENCES}

[1] "Provinsi Kepulauan Bangka Belitung Dalam Angka Kepulauan Bangka," Badan Pusat Statistik, 2019.

[2] "Peta Wilayah Administrasi Provinsi Kepulauan Bangka," Badan Nasional Penanggulangan Bencana, 2009.

[3] Y. Tiandho, I. Dinata, W. Sunanda and R. F. G. a. D. Novitasari, "Solar energy potential in BangkaBelitung islands, Indonesia.," in IOP Conference Series: Earth and Environmental Science, 2019.

[4] T. Jensen, "Renewable energy on small islands," Forum for energy and development, 1998.

[5] P. Madub, P. Appavoo and A. Chiniah, "Evaluation of IoT for Automisation of Solar Map Production:Case of Mauritius and Outer Islands," in IEEE Global Conference on Internet of Things (GCIoT), 2019.
[6] D. Surroop, P. Raghoo and Z. Bundhoo, Comparison of energy systems in Small Island Developing, Elsevier, 2018.

[7] Y. Kuang, Y. Zhang, B. Zhou, C. Li, Y. Cao, L. $\mathrm{Li}$ and $\mathrm{L}$. Zang, A review of renewable energy utilization in islands. Renewable and Sustainable Energy Reviews, Elsevier, 2016.

[8] S. Adhya, D. Saha, A. Das, J. Jana and H. Saha, "An IoT based smart solar photovoltaic remote monitoring and control unit communication (CIEC)," in 2nd international conference on control, instrumentation, energy \&, 2016.

[9] S. Madeti and S. Singh, "Monitoring system for photovoltaic plants: A review Renewable and Sustainable Energy Reviews," Renewable and sustainable Energy Reviews, vol. 67, pp. 1180 1207, 2017.

[10] P. M. Badave, B. Karthikeyan, S. M. Badave, S. B. Mahajan and P. S. a. G. S. Gill, "Health Monitoring System of Solar Photovoltaic Panel: An Internet of Things Application," in Advances in Smart Grid and Renewable Energy, 2017, p. 347-355.

[11] R. L. Babu, D. Rambabu, A. R. Naidu, R. D. Prasad and P. G. Krishna, "IoT Enabled Solar Power Monitoring System," International Journal of Engineering \& Technology, vol. 7, no. 3, pp. 526-530, 2018.

[12] H. Subastiyan, W. Sunanda and R. F. Gusa, "A Prototype of Monitoring Temperature and Humidity on," in IOP Conference Series: Earth and Environmental Science 520, 2020.

[13] I. M. M. Garcia, E. J. P. Garcia, V. P. Lopez, I. Santiago, M. J. G. Redondo, M. V. Martinez and R. J. R. Calvo, "Real-Time Monitoring System for a Utility-Scale Photovoltaic Power Plant Sensors," Sensors, vol. 16, no. 6, p. 770, 2016.

[14] W. S. R F Gusa, I. D. I and T. P. Handayani, "Monitoring system for solar panel using smartphone-based on microcontroller," in 2nd International Conference on Green Energy and, 2018. 
[15] N. Stroia, D. Moga and Z. Barabas, "Web-based monitoring of solar power systems," in IFAC, 2013.

[16] S. Syafii, M. I. Rusydi, L. Son and I. Zikri, "Webbased Net Energy Meter for Grid-Connected PV," TEM, vol. 1, p. 9, 2020.

[17] T. Hu, M. Zheng, J. Tan, L. Zhu and W. M. W, Intelligent photovoltaic monitoring based on solarirradiance big data and wireless sensor networks Ad Hoc Networks, vol. 35, Elsevier, 2015, p. 127-36.

[18] W. Winasis, A. W. W. Nugraha, I. Rosyadi and F. S. T. Nugroh, "Desain Sistem Monitoring Sistem Photovoltaic Berbasis Internet of Things (IoT)
Jurnal Nasional Teknik Elektro dan Teknologi Informasi (JNTETI)," Jurnal Nasional Teknik Elektro dan Teknologi Informasi (JNTETI), vol. 4, p. 5, 2016.

[19] F. P. Su, Z. C. Chen, H. F. Zhou, L. J. Wu, P. J. Lin, S. Y. Chang and Y. F. Li, "distributed monitoring system for photovoltaic arrays based on a two-level wireless sensor network," in IOP Conference Series: Earth, 2017.

[20] S. B. N. S. S Priyadarshi, "Inexpensive System for Large Scale, Wireless, Remote Temperature Monitoring of Photovoltaic Modules," in IEEE 7th World Conference on Photovoltaic Energy Conversion (WCPEC), 2018. 